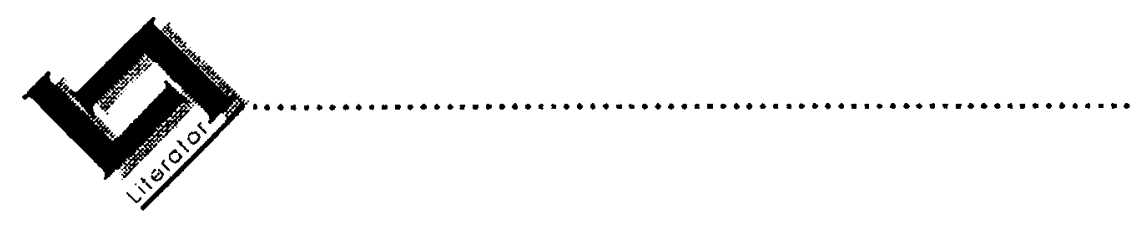

\title{
Taalversorging - teoreties gefundeer in die taalpraktyk? ${ }^{1}$
}

\author{
A. du Plessis \& W.A.M. Carstens \\ Vakgroep Afrikaans en Nederlands \\ Skool vir Tale en Kunste \\ Potchefstroomse Universiteit vir $\mathrm{CHO}$ \\ POTCHEFSTROOM \\ E-pos: aduplessis@unam.na \\ afnwamc@puknet.puk.ac.za
}

\section{Abstract}

Language editing - theoretically grounded in language practice?

This article focuses on the possibility of formulating a theory of language editing. Research indicates that language editing in practice is sometimes undertaken on a random basis. People tend to think that language editing comes naturally once a person has completed a language course. This is of course not true. Language editing should be implemented on a sound theoretical basis embedded in a strong linguistic framework. This theoretical grounding is based on a thorough knowledge and implementation of linguistic subdisciplines: a command of language (linguistic competence), text linguistics and normative grammar. These three linguistic subdisciplines form an integrated basis for a sound theoretical viewpoint on language editing. Furthermore, the term "language editing" is inadequate to describe the editing process as a whole. Language editing should not be simply seen as the correction of language errors, but rather as a complete editing (copy-editing) of the text.

$1 \quad$ Hierdie artikel is gebaseer op 'n M.A.-verhandeling met as titel Die teorie en praktyk van taalversorging - 'n Loodsondersoek wat Adele du Plessis in 1997 onder leiding van prof. W.A.M. Carstens aan die PU vir $\mathrm{CHO}$ voltooi het. Dit is ook as referaat gelewer tydens die LVSA se 1998-jaarkongres te Potchefstroom (Julie 1998) en word hier in 'n aangepaste en verwerkte vorm as artikel aangebied. 


\section{Inleiding}

Taalversorging vind al jare op 'n lukraak wyse in die praktyk plaas. Dit blyk duidelik uit die resultate van dataversameling wat met behulp van vraelyste saamgestel is (Du Plessis, 1997:109-110). Hieruit kom na vore dat werkgewers/opdraggewers geneig is om te dink dat enige persoon wat 'n taalkursus voltooi het, "taalversorging" kan doen.

Dit is egter so dat nie almal wat 'n taalkursus suksesvol afgelê het, noodwendig ook 'n goeie taalpraktisyn is nie. De Vries (1994:310) verwys in sy bekende "Titanic"-artikel hierna as hy ' $n$ veelgehoorde klag uit die sakesektor aanhaal:

Ons kan studente met ' $n$ universiteitsgraad in Afrikaans nie in ons onderneming gebruik sonder ekstra opleiding nie, want hulle weet nie hoe om 'n vers/ag/brief/stuk/kopié/beleidsdokument, ens. op te stel nie.

Dan het hy nie eens verwys na opmerkings vanuit koerantkantore dat afgestudeerde studente nie ordentlike redigeringswerk kan doen nie en dat sommige van hulle bykans "onbruikbaar" in joernalistieke subkantore is - dat hulle in der waarheid indringende indiensopleidingsprogramme moet ondergaan (vgl. Kotze 1998:29-30). In die inleidende gedeeltes tot die gesaghebbende Leren Communiceren van Steehouder et al. (1992: 12) word ook melding gemaak van studente se taalpraktyksonvermoë: "Studenten zouden hun studiestof niet behoorlik kunnen verwerken; zij zouden niet helder kunnen formuleren; verslagen en scripties kosten te veel tijd en de resultaten laten te wensen over." Die probleem hiermee is dat soveel van hierdie studente mettertyd taalversorgers word en dat hierdie soort gebreke dan deel word van hulle taalversorgingsapparaat.

Navorsing (vgl. Du Plessis 1997; Kotze 1998) dui daarop dat taalversorging op 'n deeglik gefundeerde wyse gedoen behoort te word om hierdie (en ander) gebreke uit te skakel. Inligting oor die fundering van taalversorging as teoretiese subdissipline is feitlik niebestaande (vgl. Du Plessis, 1997:1-3), maar uit die navorsing waarop hierdie artikel gebaseer is, het dit geblyk dat die moontlike teoretiese fundering van so 'n dissipline grotendeels berus op 'n deeglike taalkundige kennis van die subdissiplines taalgebruikskunde, tekslinguistiek en normering. Sáám vorm hierdie drie subdissiplines 'n geïntegreerde basis vir taalversorging, aldus Du Plessis (1997:3). Deur die bestudering van relevante aspekte van dié drie subdissiplines word gepoog om 'n teorie vir taalversorging tot stand te bring.

In hierdie kort artikel word ook gepoog om (a) 'n aanduiding te gee waarom ' $n$ teoretiese fundering van belang is vir die opleiding van 
taalversorgers en (b) waarom juis hierdie drie komponente so ' $n$ groot rol speel in die totstandkoming van 'n teoretiese model.

\section{Taalversorging: 'n omskrywing}

Taalversorgers het baie pligte en funksies, maar die primêre taak van die taalversorger is om ' $n$ teks presieser, saakliker en betekenisvoller te maak as wat dit oorspronklik was (vgl. Du Plessis 1997:91; Kotze 1998:61-62). Alle skrywers se werk, ongeag die vlak van ervaring, het versorging nodig, aldus Bowels et al. (1993:4). Die betrokke tekste vereis versorging omdat 'n teks vol foute die leser sal irriteer en die leesproses asook die konseptualiseringsproses negatief sal beïnvloed. Volgens Judd (1982:1) vereis taalversorging (copy-editing) "... close attention to everyday detail in a manuscript, a thorough knowledge of what to look for and the style to be followed, and the ability to make quick, logical, and defensible decisions". Hierdeur slaag die taalversorger daarin "... (to) knock off rough edges and make copy understandable, so the reader gets maximum return on minimum effort" (Gibson, 1979:24).

Die taalversorger moet dus na die teks as geheel kyk en nie slegs die taalgebruik kontroleer en verbeter nie. Daar moet naamlik ook aandag geskenk word aan sake soos lettertipe en -grootte, skemas en diagramme, verwysings en bladsynommers, met ander woorde aan die algemene uitleg en tipografie asook styl en duidelik verstaanbare taalgebruik. Hieruit blyk dit duidelik dat die tradisionele term taalversorging eintlik nie genoegsaam is om die voile omvang van die redigeringsproses aan te dui nie - taalversorging as proses moet nie net beskou word as die korrigering van taal nie, maar ook as die versorging van die teks as geheel, met ander woorde die totale produk en nie net ' $n$ deel (taalgebruik) daarvan nie. In hierdie verband kry die term teksversorging deesdae al hoe meer voorkeur (vgl. Du Plessis, 1997:23; Kotze, 1998:119 e.v.)2.

Cheney (1983) gee in die inleiding van sy boek 26 begrippe weer wat vir hom die hele taalversorgingsproses saamvat, naamlik:

... writing, rereading, reviewing, rethinking, rearranging, repairing, restructuring, reevaluating, editing, tightening, sharpening, smoothing, pruning, polishing, punching up, amending, emending, altering, eliminating, transposing, expanding, condensing, connecting, cohering, unifying, perfecting.

2 Die kwessie van taalversorging vs. teksversorging vs. proeflees word nie hier verder beredeneer nie. Vir 'n oorsig oor die problematiek verbonde aan hierdie terme vergelyk Kotze (1998: 119 e.v.). 
Hieruit blyk dit duidelik dat taalversorging nie 'n eenvoudige takie is wat gou afhandel kan word nie, al dink opdraggewers dalk so (vgl. Kotze, 1998:144-147). Dit behels naamlik die totale proses waardeur die teks gaan om dit gereed te kry vir die drukproses (Du Plessis, 1997:92). Dit is ' $n$ ingewikkelde taak wat algehele linguistiese kompetensie vereis - en hierdie vermoë behoort 'n stewige teoretiese basis te hê (vgl. Du Plessis, 1997:3).

\section{Waarom 'n teorie vir taalversorging?}

Taalversorging vind volgens Du Plessis (1997:1) al jare lank op 'n willekeurige en ongekontroleerde wyse plaas. Dit is byvoorbeeld nog nie verpligtend vir ' $n$ persoon om aan 'n geakkrediteerde organisasie soos die SA Vertalersinstituut (SAVI) te behoort voordat sy/hy taalversorging mag doen nie. Dit gebeur dikwels dat 'n persoon wat "iets" van linguistiek weet of ' $n$ taalkursus geslaag het, hom/haar bevoeg voel om as "taalversorger" op te tree, hoofsaaklik omdat daar (meestal beduidende) finansiële voordele aan hierdie werk verbonde is.

Tradisioneel is daar nét vanuit 'n normeringsoogpunt na tekste gekyk in die taalversorgingsproses ( $v g l$. Fryer, 1988, 1997; Koch, 1988). Uit die beskikbare bronne met betrekking tot taalversorging ( $\mathrm{vgl}$. Du Plessis, 1997:91 e.v.) blyk dit dat in die taalversorgingsproses hoofsaaklik aandag geskenk is aan sake soos spelling, interpunksie, korrekte woordorde en die korrekte woordkeuse. Danksy die insigte van onder andere die taalbeheersers ( $\mathrm{vgl}$. onder meer Steehouder et al., 1992), het hedendaagse taalversorgers tot die besef gekom dat taalversorging méér behoort te behels as nét normering. Soos reeds hier bo in afdeling 2 genoem is, behoort die teks as geheel (taal sowel as alle ander tekstuele aspekte) beoordeel te word, en daarom is ook onder meer kennis van bladuitleg, koherensie en kohesie 'n vereiste. Vir die taalversorger is dit nie meer moontlik om net op voorgraadse linguistiese kennis te steun om hierdie taak aan te pak nie; grondige, resente en gevorderde linguistiese kennis is naamlik nodig (Du Plessis, 1997:119120).

In terme van die beginsels van die taalgebruikskunde (wat veral fokus op skriftelike kommunikasie), is dit noodsaaklik dat die skrywer nie net die gepaste woordkeuses sal uitoefen nie, maar ook seker sal wees van onder meer die spelling, betekenis, styl en interpunksie om sodoende die bedoeling duidelik oor te dra (vgl. Judd, 1982; Renkema, 1989; Steehouder et. al., 1992; Van der Horst, 1996; Van der Horst, 1997). 'n Swak versorgde teks kan tot gevolg hê dat die verkeerde boodskap oorgedra word en dit sal uiteraard oneffektiewe kommunikasie meebring. Combrink (1995:1) se belangrike kriterium van "100\% kommunikasie die 
eerste keer" word derhalwe nie nagekom nie. Die skrywer of taalgebruiker moet in gedagte hou dat die teks namens die skrywer, as verteenwoordiger van die skrywer se idees by die leser, optree. Deur 'n goed versorgde teks bou die leser 'n positiewe beeld op van die skrywer; 'n swak versorg de teks gaan beslis nie 'n positiewe beeld oordra nie.

\section{Drie linguisties-begronde modelle vir taalversorging}

Volgens Du Plessis (1997:2-3) se navorsing blyk dit dat na 'n verskeidenheid linguistiese benaderings of dissiplines gekyk behoort te word in 'n poging om ' $n$ moontlike teoretiese model vir taalversorging tot stand te bring. Elk van die geïdentifiseerde dissiplines, te wete taalgebruikskunde, tekslinguistiek en normering, is ondersoek ten einde te probeer bepaal wat die waarde van elkeen vir die taalversorger sou wees (vgl. Du Plessis, 1997:16 e.v.). Die premis was dat begrip en kennis van hierdie dissiplines sou bydra tot die skep van 'n raamwerk vir 'n (eksplisiete) teorie vir taalversorging. Die onderskeie elemente wat deel vorm van so 'n teoretiese raamwerk sal dit duidelik maak dat 'n taalversorger om verskeie redes oor 'n breë linguistiese agtergrond moet beskik om enigsins (kwaliteit) taalversorging te kan doen.

\subsection{Taalgebruikskunde en die taalversorgingsproses}

Taalgebruikskundeltaalbeheersing ${ }^{3}$ is 'n subdissipline wat klem plaas op kommunikasie ( $\mathrm{vgl}$. onder meer Van den Hoven \& Korpel, 1989:17; Steehouder et al., 1992; Braet \& Van de Gein, 1993), en dit word deur die meeste taalbeheersers beskryf as die proses waardeur 'n mens funksionele taalgebruik evalueer en analiseer ( $V a n$ den Hoven \& Schellens, 1993:145). Braet (1980:38) is van mening dat taalbeheersing oorkoepelend beskou moet word as taalgebruikers se kommunikatiewe vermoë, waardeur die ontvanger sowel as die sender in staat gestel word om deur middel van taal inligting oor te dra en te bekom. Taalbeheersingsvelde of -gebiede wat by ondersoeke betrek is, is onder andere die argumentasieteorie, gespreksanalise, skryfteorie, skryf- en leesondersoeke, stylondersoeke en ondersoeke na taalvaardigheidsonderwys (vgl. Braet, 1988:208-216).

Alhoewel taalgebruikskunde tot by die vroeë retorici teruggevoer kan word, is taalgebruikskunde as subdissipline 'n betreklik nuwe en onont-

3 Die term taalbeheersing word veral vanuit Nederlandse perspektief gebruik (vgl. onder meer Braet (red.), 1980; Jansen \& Verhoeven, 1989; Steehouder et al., 1992; Braet \& Van Gein, 1993). In Afrikaans word die term taalgebruikskunde tans hiervoor gebruik (vgl. De Vries, 1994). 
ginde dissipline in Afrikaans (vgl. De Vries, 1994). Tydens die voorondersoek het dit duidelik geword dat taalgebruikskunde as dissipline nie afsonderlik van ander dissiplines funksioneer nie.

Maes et al. (1994:1-4) verwys dan ook na die interdissiplinêre karakter van taalgebruikskunde. Hulle voer aan dat taalgebruikskunde/ taalbeheersing nie gesien moet word as ' $n$ tradisionele taalkundige dissipline soos byvoorbeeld algemene taalwetenskap of semantiek nie, maar eerder as ' $n$ interdissiplinêre studieterrein. Hulle voer die volgende rede aan:

$(H)$ et taalbeheersingsonderzoek zoekt qua onderzoekvraag en methode immers inspiratie by tradisionele letterendisciplines, zoals de pragmatiek, de (teks)semantiek, de logika, de psycholinguïstiek, de sociolinguïstiek, de taalfilosofie en zelfs bij niet-letterendisciplines zoals de sociologie en psychologie.

Volgend Braet (1988:207-208) het hierdie interdissiplinêre karakter besondere waarde, want taalgebruikskunde as vak betrek al die ander dissiplines wat 'n rol speel by die opstel van modelle vir taalversorging. Op grond hiervan kan tereg aangevoer word dat taalgebruikskunde as dissipline om verskeie redes belangrik is vir die taalversorger (vgl. Du Plessis, 1997:59 e.v.).

- Eerstens word die taalversorger se linguistiese kennis van ander subdissiplines deur die interdissiplinêre aard van die taalgebruikskunde betrek. Die onderskeie subdissiplines funksioneer nou nie meer as afsonderlike komponente nie, maar vorm 'n koherente eenheid. Die taalversorger as taalgebruikskundige betrek en pas dus alle relevante kennis tydens die versorgingsproses toe, soos byvoorbeeld pragmatiese en stilistiese kennis.

- Tweedens is taalgebruikskunde taakspesifiek (die skrywer kry 'n opdrag om 'n spesifieke produk te lewer; vgl. Enning \& Van Steen, 1989:103) en plaas dit meer klem op die proses as op die produk (die proses is die fisiese skryf van die produk of die proses kan ook aanleiding gee tot die lees daarvan). Vir die taalversorger lê die belang daarin dat die oorsprong van foute maklik vasgestel kan word as die taalversorger en die skrywer bewus is van die oorsake daarvan. Foute ontstaan dikwels tydens die skryfproses en daarom is dit belangrik dat die taalversorger ook oor kennis van die skryfproses sal beskik.

- Laastens word die beoordeling van 'n teks ook vergemaklik deur die raamwerk van die taalgebruikskunde. Die taalgebruikskunde (vgl. 
Breetvelt et al., 1994:108) stel die volgende vier hoofpunte daar vir die beoordeling van tekste:

\begin{tabular}{|l|l|}
\hline Doelwitbeplanning: & $\begin{array}{l}\text { Let daarop of die teks gefokus is. } \\
\text { Is al die doelwitt wat vooraf } \\
\text { gestel is, deur die skrywer } \\
\text { bereik? }\end{array}$ \\
\hline Teksstruktuur en -organisering: & $\begin{array}{l}\text { Let op na die paragrafering, } \\
\text { kohesie in die teks en tussen } \\
\text { paragrawe onderling asook na } \\
\text { die uitleg van die teks. }\end{array}$ \\
\hline Lesersbewustheid: & $\begin{array}{l}\text { Betrek die skrywer die lesers? Is } \\
\text { die skrywer interaktief betrokke } \\
\text { by die lesers en hul probleme? }\end{array}$ \\
\hline Korrekte taalgebruik en styl: & $\begin{array}{l}\text { Skenk aandag aan grammatika, } \\
\text { woordeskat, registers en variasie } \\
\text { in sinskonstruksies. }\end{array}$ \\
\hline
\end{tabular}

\section{Tabel 1: Beoordeling van tekste}

'n Goed versorgde teks wat suksesvolle kommunikasie bewerkstellig, is 'n teks wat aan al onderstaande kriteria beantwoord wanneer die taalversorger dit daaraan meet.

Dit is egter van belang om in gedagte te hou dat die taalversorger en die taalbeheerser/ taalgebruikskundige nié presies dieselfde taak verrig nie. Die taalbeheerser se taak verskil van dié van die hedendaagse taalversorger daarin dat taalbeheersers metodologies fokus op die wyses waarop suksesvolle kommunikasie verseker kan word. Hierteenoor is die taalversorger die een wat die taalbeheersingsvaardighede tot uitvoering bring. Taalbeheersers wat as skryfadviseurs optree, benadruk ook die begryplikheid van taalgebruik, want daar moet tog deeglike aandag gegee word aan versorgde taalgebruik (vgl. Braet, 1980:2; Van der Horst, 1997).

Samevattend blyk dit dat kennis van taalgebruikskunde/taalbeheersing die taalversorger sal help om die hele skryf- en leesproses beter te verstaan. Verder help dit ook die taalversorger om met 'n totale linguistiese perspektief na die teks te kyk en nie net te fokus op die vlak van spelling en woordorde nie. 


\subsection{Tekslinguistiek en die taalversorgingspraktyk}

Die term tekslinguistiek het volgens Carstens (1997:6) twee moontlike interpretasies. Die eerste of aanvanklike interpretasie is ' $n$ "beperkende beskouing van die analise van die linguistiese struktuur van hoofsaaklik geskrewe tekste". Die tweede of meer resente interpretasie van die term is dat tekslinguistiek gesien moet word as 'n "oorkoepelende term vir enige linguistiese ondersoek van die teks". Uit dié twee moontlike interpretasies blyk dit dat die sentrale fokuspunt van die tekslinguistiek die teks self is (vgl. Hubbard, 1993:56). Die tekslinguistiek as dissipline plaas sterk klem op die aard van die linguistiese struktuur van tekste. Hierdie linguistiese struktuur word met behulp van 'n verskeidenheid linguistiese middele ondersoek.

Daar is drie aspekte wat van die tekslinguistiek as dissipline 'n geskikte model vir taalversorging maak (vgl. Du Plessis, 1997:89-90):

- Eerstens is daar die interdissiplinêre aard daarvan. Hierdie interdissiplinêre aard impliseer dat die tekslinguistiek nie ' $n$ afgesonderde of geïsoleerde dissipline is nie, maar dat dit ook steun op kennis en vaardighede uit ander dissiplines. Die teksversorgers sal dus nie langer alleen op grammatikale kennis (sintaksis en morfologie) kan steun nie, maar sal ook moet beskik oor linguistiese vaardighede in die algemeen en in staat wees om dit te kan toepas tydens die (taal)versorgingsproses.

- Tweedens is daar die geïmpliseerde kennis van tekstipes, wat baie belangrik is vir die taalversorger, omdat die aard van die teks bepalend is vir die vorm en inhoud van die teks (vgl. Carstens, 1997: 85-93). Voordat 'n teksversorger byvoorbeeld 'n wetenskaplike verslag kan versorg, moet hy/sy deeglik bewus wees van die aanvaarbare vorm en struktuur van so 'n verslag.

- Laastens is daar die beginsels van tekstualiteit. Hierdie beginsels (of standaarde) vorm die kern van die tekslinguistiek as navorsingsterrein (vgl. De Beaugrande \& Dressier, 1981:1-3; Carstens, 1997:26-28). Die taalversorger kan derhalwe die geldigheid van die teks bepaal deur gebruik te maak van die sewe onderskeide beginsels van tekstualiteit soos aangedui deur De Beaugrande en Dressler (1981) (vgl. ook Carstens, 1989, 1993 en 1997): 
Kohesie (Op watter wyse sluit die taalelemente by mekaar aan?)

$$
\begin{array}{ll}
\Rightarrow & \text { verwysing } \\
\Rightarrow & \text { substitusie } \\
\Rightarrow & \text { ellips } \\
\Rightarrow & \text { leksikale kohesie } \\
\Rightarrow \text { konjunksie } &
\end{array}
$$

Koherensie (Lees die teks vloeiend en logies?)

Intensionaliteit (Wat is die intensie van die skrywer? Wat wil bereik word?)

Aanvaarbaarheid (Die leser se gesindheid teenoor die teks.)

Informatiwiteit ('n Teks moet inligting oordra; die tekslading word bepaal deur die hoeveetheid ou en nuwe inligting.)

Kontekstualiteit (Die rol van die kontekste waarbinne die teks voorkom.)

Intertekstualiteit (Die moontlikheid dat kennis van een tekstruktuur die interpretasie van ander soortgelyke teksstrukture kan beinvloed.)

\section{Tabel 2: Beginsels van tekstualiteit}

Die vraag ontstaan nou: Waarom het die taalversorger kennis van die tekslinguistiek nodig? Carstens (1993:9) bespreek die praktiese implikasies van die beginsels van tekstualiteit en kom tot die gevolgtrekking dat die tekslinguistiek daartoe bydra dat die taalversorger oor die volgende vermoëns vir die taalversorgingsproses beskik, naamlik:

- kennis van die taalkundige eienskappe van tekste;

- 'n bewustheid van die struktuur van 'n teks;

- 'n bewustheid van die leksikogrammatikale elemente wat daartoe bydra dat ' $n$ teks 'n eenheid vorm;

- die vermoë om die kommunikatiewe funksie van tekste te bepaal en om vas te stel of dit geslaagd is;

- die vermoë om vas te stel of die gedeelde kennis (tussen sender en ontvanger) ' $n$ invloed sal hê op die lees van 'n teks;

- die vermoë om die invloed van die konteks te kan bepaal;

- die vermoë om die tekstipe van 'n teks te bepaal, en op grond hiervan te kan aandui in watter mate die versorgde teks aan die eienskappe van die betrokke tekstipe voldoen. 
Samevattend blyk dit dat die beginsels van tekstualiteit 'n nuttige hulpmiddel is by die vasstel van die begrip "teks", veral omdat die skrywer en leser se vermoë om te kommunikeer, bepaal kan word en die relevante tekstipes geidentifiseer kan word (vgl. Carstens, 2000).

\subsection{Normering en die taalversorgingspraktyk}

Taalgebruikers wil dikwels weet of 'n bepaalde woord of uiting "reg" of "verkeerd" is. Volgens Renkema (1985: 38) sê die taalgebruiker: "Ik wil weten of iets goed of fout is. Geef mij regels!", en Van der Horst (1996: 26) skryf dat die vraag na norme en reëls op sigself nie sleg, verkeerd of dom is nie, want die taalgebruikers ervaar hierdie taalkeuses as verwarrend (vgl. ook Carstens, 1994:5).

Op grond van norme word bepaal wat reg, goed en aanvaarbaar is. Norme is deel van 'n mens se lewe en speel ' $n$ rol op elke terrein van menswees, maar dit is die implikasies van taalnorme vir die taalversorger wat hier ter sprake is (vgl. Carstens, 1994:3-4). Taalnorme het ' $n$ invloed op verskillende taalvlakke: dit is moontlik om norme neer te lê vir klankvorme, skrifvorme, woordeskat, sintaktiese en morfologiese eienskappe van woorde en verskillende style en registers (Steyn, 1985: 42; Carstens, 1994:24-25).

Die volgende onderskeidings ten opsigte van normering op die onderskeie taalvlakke en die implementering daarvan deur die taalversorger is belangrik vir die taalversorger:

\begin{tabular}{|l|l|}
\hline $\begin{array}{l}\text { Fonologiese } \\
\text { vlak: }\end{array}$ & $\begin{array}{l}\text { Daar kan van die taalversorger verwag word om } \\
\text { beperkte uitspraakleiding te verskaf. Du Plessis en } \\
\text { Wissing (1984:68-69) wys daarop dat foutiewe } \\
\text { spelling dikwels 'n fonologiese oorsaak het, omdat } \\
\text { mense letterlik skryf soos hulle praat of hoor. Indien } \\
\text { die taalversorger bewus is van hierdie klank- } \\
\text { verskynsels, kan die foutiewe spelling verklaar en } \\
\text { gekorrigeer word. }\end{array}$ \\
\hline $\begin{array}{l}\text { Morfologiese } \\
\text { vlak: }\end{array}$ & $\begin{array}{l}\text { In die morfologie word die vorm, funksie en die } \\
\text { betekenis van woorddele bestudeer. Vir die taal- } \\
\text { versorger kan kennis van die taal se morfologie dus } \\
\text { op verskeie vlakke van belang wees, soos byvoor- } \\
\text { beeld by meervoudsvorming, trappe van vergelyking, } \\
\text { verkleiningsvorme en die foutiewe gebruik van die } \\
\text { verboë -e veral by die letterlike en figuurlike gebruik } \\
\text { van woorde (Carstens, 1994:74-91). }\end{array}$ \\
\hline
\end{tabular}




\begin{tabular}{|l|l|}
\hline $\begin{array}{l}\text { Sintaktiese } \\
\text { vlak: }\end{array}$ & $\begin{array}{l}\text { Op hierdie vlak word aandag geskenk aan die } \\
\text { struktuur en funksies van die sintaktiese elemente. Dit } \\
\text { gaan met ander woorde hier vir die taalversorger } \\
\text { veral oor die woordvolgorde in sinne: Afrikaans as } \\
\text { SvO-taal, die woordorde na die gebruik van 'n } \\
\text { voegwoord, die volgorde van die bywoordelike } \\
\text { bepalings (tyd, wyse, plek) en die dubbele ontkenning } \\
\text { in Afrikaans. }\end{array}$ \\
\hline $\begin{array}{l}\text { Leksikologiese } \\
\text { vlak: }\end{array}$ & $\begin{array}{l}\text { Hier word gekonsentreer op die leksikon van die taal, } \\
\text { met ander woorde die totale woordeskat van die taal } \\
\text { en hiermee saam die leksikografie wat 'n verwerking } \\
\text { is van 'n spesifieke deel van die woordeskat. Kennis } \\
\text { van woordeboeke sal ook hier ter sprake kom. }\end{array}$ \\
\hline Grafiese vlak: & $\begin{array}{l}\text { Normering op grafiese vlak sluit twee aspekte in, } \\
\text { naamlik spelling en interpunksie (leestekens, skryf- } \\
\text { tekens en proefleestekens). Hierdie vlak is dan ook } \\
\text { die vlak waarop die meeste mense (nieprofessionele } \\
\text { taalversorgers) konsentreer wanneer hulle 'n teks } \\
\text { versorg. }\end{array}$ \\
\hline Stilistiese vlak: & $\begin{array}{l}\text { Die wyse waarop 'n persoon sy gedagtes verwoord, } \\
\text { hetsy mondeling of skriftelik, kan onder een } \\
\text { oorkoepelende term saamgevat word, naamlik styl. } \\
\text { Berner (1982:52) skryf dat 'n taalversorger styl nie } \\
\text { moet beskou as sinlose detail nie, "but a way of } \\
\text { keeping consistency and thus the credibility of the } \\
\text { paper alive". Hier sal die graad van formaliteit ook 'n } \\
\text { rol speel en die taalversorger moet dus vooraf vasstel } \\
\text { vir wie hierdie teks bedoel is en of die vlak van } \\
\text { formaliteit by die lesers gaan pas, maar ook of die } \\
\text { vlak van formaliteit by die inhoud van die teks pas. }\end{array}$ \\
\hline
\end{tabular}




\begin{tabular}{|l|l|}
\hline $\begin{array}{l}\text { Pragmatiese } \\
\text { vlak: }\end{array}$ & $\begin{array}{l}\text { Pragmatiese taalgebruik is die korrekte of gepaste } \\
\text { taalgebruik vir 'n gegewe konteks. Registers en kodes } \\
\text { is twee belangrike aspekte waaraan aandag gegee } \\
\text { moet word op hierdie vlak. Daar moet vasgestel word } \\
\text { of die taalgebruik in die teks die aard van die teks } \\
\text { weerspieël. As dit byvoorbeeld 'n teks is wat spesifiek } \\
\text { vir 'n mediese tydskrif geskryf is, mag die skrywer }\end{array}$ \\
gebruik maak van vaktaal. Indien hierdie teks vir 'n \\
meer algemene lesersgehoor bedoel is, moet probeer \\
word om die vakkundige jargon te vermy.
\end{tabular}

\section{Tabel 3: Taalvlakke}

Hierdie taalvlakke word daagliks deur die taalgebruiker gebruik, hetsy gepas of minder gepas, en 'n taalversorger behoort daarom des te meer bewus te wees van al hierdie taalvlakke, asook van hul normeringsimplikasies. Wanneer ' $n$ taalversorger 'n teks versorg, moet hy/sy kennis dra van al hierdie taalvlakke, asook van die reëls van elke taalvlak.

Taalversorgers moet ook in staat wees om al die afwykings van die standaardtaal te identifiseer en die normeringsreëls toe te pas. Verder is 'n deeglike kennis van taalnorme nodig (soos byvoorbeeld opgeteken vir Afrikaans deur onder meer Carstens, 1994; vgl. ook Botha \& Sinclair (reds.), 1985), sodat die taalversorger 'n gemotiveerde keuse kan uitvoer. 'n Kliënt wil naamlik graag weet waarom die taalversorger sekere veranderinge in die teks aangebring het.

Die volledige versorging van 'n teks behels meer as net die "kosmetiese" veranderinge van spelling en interpunksie (vgl. Du Plessis, 1997:58; Kotze, 1998:62-63). Die teks moet ook aan die vereistes van pragmatiese korrektheid, goeie styl, fonologiese en morfologiese korrektheid, sintaktiese eenheid en leksikologiese korrektheid voldoen ( $\mathrm{vgl}$. weer tabel 3). Die presiesheid van woorde is noodsaaklik om die boodskap duidelik oor te dra. 'n Taalversorger moet op hoogte wees van alle taalkundige reëls en konvensies om sodoende aan die (verskeidenheid) eise van die kliënt te kan voldoen.

\section{Samevatting: taalversorging - teoreties gefundeerd?}

Die titel van hierdie artikel is: "Taalversorging - teoreties gefundeer in die taalpraktyk?" Die ondersoekers het dit dan ook ten doel gehad om die belang van teoretiese beginsels vir die praktyk van taalversorging te ondersoek. 
Die eerste probleem waarmee te doene gekry is, was dat geen bron oor die teorie van taalversorging opgespoor kon word nie. Om dié probleem die hoof te bied is besluit om die moontlike teorie aan die hand van modelle te bestudeer. Hierdie modelle bestaan uit enkele linguistiese dissiplines, naamlik: taalgebruikskunde/taalbeheersing, tekslinguistiek en normering. Hierdie drie dissiplines dien volgens Du Plessis (1997) se navorsing as grondslag vir die teoretiese fundering van taalversorging. Dié drie dissiplines is bestudeer met die oog op die implikasies wat dit inhou vir die taalversorger. 'n Studie van hierdie subdissiplines het getoon dat kennis van dié drie dissiplines onontbeerlik vir die taalversorger is.

Eerstens is daar aandag geskenk aan taalbeheersing/taalgebruikskunde. Kennis van die algemene taalbeheersingsmodel vergemaklik die beoordeling van 'n teks deur die toepassing van die volgende raamwerk:

- doelwitbeplanning;

- teksstruktuur en -organisering;

- leserbewustheid, en

- korrekte taal- en stylgebruik.

Die taalversorger moet bewus wees van die skrywer se doelwitstelling: wat wou hy bereik deur die teks? Behalwe vir die taal- en stylgebruik in 'n teks moet die taalversorger ook aandag skenk aan die struktuur en die organiseer van die teks. Laastens moet die taalversorger altyd bewus wees van die toekomstige leser, en die voor- en afkere van die lesers. Alhoewel daar verskille tussen tradisionele taalversorgers en taalbeheersers/taalgebruikskundiges is (vgl. Du Plessis, 1997:70), vertoon die taalbeheersers en die hedendaagse taalversorger wel ooreenkomste. Albei groepe het dit naamlik ten doel om 'n koherente en goed versorgde teks as eindproduk te hê.

Tweedens is aandag geskenk aan tekslinguistiek en die belang daarvan vir die taalversorger. 'n Tekslinguistiese kennis impliseer kennis van die eienskappe van 'n teks; die onderskeie tekstipes en die sewe beginsels van tekstualiteit. Die teks staan dus weer eens sentraal. As die taalversorger 'n teks aan die hand van die sewe beginsels sou evalueer, sal dit moontlik wees om te bepaal of die teks 'n samehangende geheel vorm wat deur die leser verstaan en geïnterpreteer sal kan word. Die struktuur, sowel as die inhoud van 'n teks kom ter sprake wanneer die taalversorger 'n teks versorg met tekslinguistiese kennis in die agterkop.

Derdens is kennis van taalnorme vir die taalversorger belangrik, want die taalversorgingsproses is in wese 'n normeringsproses - 'n proses waardeur taalversorgers die foutiewe teks moet verbeter aan die hand 
van taalkundige norme. Taalkundige norme geld ook nie net vir die korrigering van spelfoute nie, want die teks moet ook op ander vlakke versorg word. Die teks moet ook aan die vereistes van pragmatiese korrektheid, goeie styl, fonologiese en morfologiese korrektheid, sintaktiese eenheid en leksikologiese eenheid voldoen. Korrektheid op al die vlakke is nodig ter wille van suksesvolle kommunikasie.

Indien die taalversorger oor 'n kennis van normering beskik, sal sy/hy in staat wees om die taalgebruiker te lei in die maak van taal- of normkeuses. Normering het dit ten doel om die gebruik van taal te standaardiseer, te stabiliseer en te koördineer en dit behoort by uitstek ook die doelwit van elke taalversoger te wees. Die taalversorger moet toesien dat 'n teks in gepaste taal (in die meerderheid gevalle standaardtaal) geskryf is, sodat dit toeganklik vir die lesers sal wees; die woordkeuses en taalgebruik moet stabiel of konsekwent wees en die taalversorger moet die taalversorgingsproses so koördineer dat die kliënt na die tyd ' $n$ ingeligte taalgebruiker sal wees. Deur voortdurend van normeringsgronde (vgl. Carstens, 1994:22 e.v.) gebruik te maak, vergemaklik taalversorgers hul eie taak, want met behulp van hierdie normeringskennis sal hulle in staat wees om gemotiveerde veranderinge in 'n teks aan te bring.

In die geheel gesien, is dit duidelik dat 'n taalversorger oor 'n grondige linguistiese kennis moet beskik om die suksesvolle versorging van 'n talige teks te kan doen. Die belangrikste gevolgtrekking waartoe gekom is, is egter dat taalversorging baie meer behels as bloot die versorging van die taalkundige aspekte van 'n teks - taalversorging impliseer naamlik algehele teksversorging. Die benaming taalversorging is dus te beperkend en bring leke waarskynlik onder die indruk dat taalversorgers net spelfoute korrigeer. 'n Taalversorger moet egter ook aan die toekomstige leser dink, die tipografie van die teks beoordeel, sorg dat die teks samehang toon en dat dit vloeiend en verstaanbaar sal lees.

Die taalversorger moet in staat wees om 'n onversorgde teks, wat dalk vol foute is, te omskep in ' $n$ afgeronde stuk werk (produk) en om dit te kan doen, is gefundeerde teoretiese kennis nodig. Dit blyk uit navorsing (Du Plessis, 1997; Kotze, 1998; Van der Horst, 1997) dat taalversorging al lank nie meer net die "regmaak" van basiese taalgebreke is nie en dat daar inderdaad ' $n$ stewige teoretiese begronding nodig is om reg te laat geskied aan die praktyk wat met hierdie belangrike taalaktiwiteit gepaard gaan.

\section{Bibliografie}

Berner, R.T. 1982. Editing. New York: CBS College Publishing. 
Botha, R.P. \& Sinclair, M. (reds.) 1985. Norme vir taalgebruik. Spil Plus 10 Stellenbosch : Universiteit van Stellenbosch.

Bowels, D.A., Borden, D.L. \& Rivers, W. 1993. Creative editing for printing media. California : Wadsworth.

Braet, A. (red.) 1980. Taalbeheersing als nieuwe retorica. Een historisch, programmatisch en bibliografisch overzicht. Groningen : Wolters-Noordhoff.

Braet, A. 1988. Taalbeheersing na twintig jaar. De Nieuwe Taalgids, 81 206-241.

Braet, A. 1993. Inleiding. In: Braet, A. \& Van de Gein, J. (reds.) Taalbeheersing als tekstwetenschap: terreinen en trends. Dordrecht: : ICG Publications. p. 11-21.

Breetvelt, I., Van den Bergh, H. \& Rijlaarsdam, G. 1994. Relations between writing processes and text quality: when and how? Cognition and Instruction, 12(4):103-123.

Carstens, W.A.M. 1989. De Beaugrande en Dressler (1981) se "standaarde van tekstualiteit". Suid-Afrikaanse Tydskrif vir Taalkunde, 5(2):17-32, April.

Carstens, W.A.M. 1993. Die studieterrein van die tekslinguistiek. Suid-Afrikaanse Tydskrif vir Taalkunde, Supplement 15:1-14, Mei.

Carstens, W.A.M. 1994. Norme van Afrikaans. Enkele riglyne by die gebruik van Afrikaans. 3de uitg. Pretoria : Van Schaik.

Carstens, W.A.M. 1997. Afrikaanse Tekslinguistiek - 'n Inleiding. Pretoria : Van Schaik.

Carstens, W.A.M. 2000. Tekslinguistiek en teksversorging. Suid-Afrikaanse Tydskrif vir Taalkunde. (Ter perse.)

Cheney, T.A.R. 1983. Getting the words right. How to rewrite, edit \& revise. Cincinnati, Ohio : Writer's Digest Books.

Combrink, J. 1995. Hoe om paragrawe te skryf. Kaapstad: Tafelberg.

De Beaugrande, R. \& Dressier, W.U. 1981. Introduction to text linguistics. London : Longman

De Vries, A. 1994. Wat maak die kokke op die Titanic? Tydskrif vir Taalonderrig, 28(4):309-315, Des.

Du Plessis, A. 1997. Die teorie en praktyk van taalversorging in Afrikaans - 'n loodsondersoek. Potchefstroom : PU vir CHO. (M.A-verhandeling.)

Du Plessis, H. \& Wissing, D. 1984. Taalfeite en -foute. Hersieningsoefeninge vir Afrikaans. Johannesburg : MacMillian Suid-Afrika.

Enning, J. \& Van Steen, P. 1989. Professioneel schrijven. In: Janssen, D. \& Verhoeven, G. (reds.) Taalbeheersing in Nederland. Een bundel opstellen voor W. Drop. Groningen : Wolters-Noordhof. p. 103-107.

Fryer, C. 1988. Wat verwag 'n uitgewer van die taalversorger? Enkele riglyne. Die Taalpraktisyn, 1:27-37.

Fryer, C. 1997. Jongleur, chirurg en koppelaar. Insig: 30, September.

Gibson, M.L. 1979. Editing in the electronic era. lowa: The lowa State University Press.

Hubbard, E.H. 1993. Some coherence correlates in expository writing. SA Tydskrif vir Taalkunde, Supplement 15:55-74, Mei.

Janssen, D. \& Verhoeven, G. (reds.) 1989. Taalbeheersing in Nederland. Een bundel opstellen voor $W$. Drop. Groningen : Wolters-Noordhof.

Judd, K. 1982. Copy-editing. Los Altos : Kaufmann.

Koch, H.J. 1988. 'n Ondersoek na die uitwerking van bepaalde taalorganisasiehandelinge op Afrikaans. Bloemfontein : UOVS. (M.A.-verhandeling.)

Kotze, A 1998. Die teksversorger as spookskrywer: Christelike uitgewersmaatskappye as 'n gevallestudie. Potchefstroom : PU vir CHO. (M.A. verhandeling.) 
Maes, A., Van Hauwermeiren, P. \& Van Waes, L. (reds.) 1994. Perspectieven in taalbeheerstugsonderzoek. Dordrecht : ICG Publications.

Renkema, J. 1985. Over regels en normen in taalgebruik. Onze Taal, 54(11):138141

Renkema, J. 1989. Schrijfwijzer. Den Haag : Sdu Uitgevers.

Steehouder, M., Jansen, C., Maat, K., Van der Staak, J. \& Woudstra, E. 1992. Leren communiceren. Groningen : Wolters-Noordhoff.

Steyn, J.C. 1985. Algemene aspekte van taalnormering. In: Botha, R.P. \& Sinclair, M. (reds.) Norme vir Taalgebruik. Spil Plus 10. Stellenbosch : Universiteit van Stellenbosch. p. 13-64.

Van den Hoven, P.J. \& Korpel, L. 1989. Het spel en de knikkers; een analyse van het begrip "functionele context". In: Janssen, D. \& Verhoeven, G. (reds.) Taalbeheersing in Nederland. Een bundel opstellen voor W. Drop. Groningen : Wolters-Noordhof. p. 13-28.

Van den Hoven, P. \& Schellens, P.J. 1993. Taalgebrujk en zjin maatschappelijke context. In: Braet, A. \& Van de Gein, J. (reds.) Taalbeheersing als tekstwetenschap: terreinen en trends. Dordrecht : ICG Publications. p. 146-176.

Van der Horst, J. 1996. Over gezag en norm in taaladvisering. Onze Taal, 65(1):2829, Januarie.

Van der Horst, P.J. 1997. Redactiewijzer. Den Haag : Sdu Uitgevers.

\section{Kernbegrippe:}

linguistiese subdissiplines, kennis van

normatiewe grammatika

taalbeheersing

taalpraktyk

taalversorging, teorie van

tekslinguistiek

Key concepts:

language command

language editing, theory of

language practice

linguistic subdisciplines, knowledge of normative grammar

text linguistics 